manities, the Quest for Truth Foundation, and the US Department of Defense Legacy Program. The book has been published in a large format, with a generous assortment of maps and photographs, and a particularly attractive reproduction of war art on the dust cover.

The only real criticism that can be levelled at this book is that, like any collection of specialized papers, it is not a very good or accessible introduction to the subject of Alaska and World War II, since it presupposes a fair amount of knowledge of the subject covered. But it is evidently not intended to serve this purpose; instead, it provides for the specialist the current state of scholarship on the subject. It will stand as a valuable source of scholarship, explanation, and personal recollection of events concerning the war, but the general reader wanting an overview of the subject should first consult one of the general histories of the state, such as Naske and Slotnik's Alaska: a history of the 49th state. Given some previous knowledge of the subject, this book is a treasure house of information. (William R. Morrison, University of Northern British Columbia, Prince George, British Columbia, Canada.)

\section{STRUCTURE, FUNCTION AND EVOLUTION OF} TEETH. Patricia Smith and Eitan Tchernov (Editors). 1992. London and Tel Aviv: Freund Publishing House. $570 \mathrm{p}$, illustrated, soft cover. ISBN 965-222-270-4.

Smith and Tchernov's edited volume is based upon papers presented at the 8th International Symposium on Dental Morphology. The Symposium provided a forum for palaeontologists, embryologists, dental anthropologists, anatomists, and geneticists to exchange information on the microstructure, embryology, morphology, function, and evolution of teeth. Of particular relevance to researchers interested in the biology of the north are two chapters in the third section dealing with human populations.

The first is by J.T. Mayhall and L. Alvesalo, and deals with sexual dimorphism in the maxillary first molars in the residents of the island of Hailuoto in Finland. Although the dental health and genetics of this population have been extensively investigated since the 1970 s, little research has been conducted on its dental morphometrics. Mayhall's and Alvesalo's results suggest that while the Hailuoto islanders' cusp heights are similar to those reported in Japanese and Canadian Inuit populations, the overall relationship is stronger to mainland Finnish patterns and other Caucasians.

The second paper of relevance to northern anthropology is by G.R. Scott and V. Alexandersen, and explores dental morphological variation among medieval Greenlanders, Icelanders, and Norwegians. The authors' aim was to assess evidence for possible gene flow from the Inuit into the Norse Greenlandic population between the tenth and sixteenth centuries. Their findings are that in the Greenlandic Norse skeletons there is temporal stability in oral health parameters (such as caries, antemortem tooth loss, and periapical osteitis), along with decreases in overall body size and increasing third molar agenesis. These are traits associated with contemporary populations in Iceland and Norway, and suggest an overall congruence with European dental patterns. However, the study also indicated that the Greenlandic Norse showed significant changes in the frequency and expression of oral tori, characters more commonly associated with Inuit populations. It was concluded that there was no incontrovertible evidence for gene flow between Norse and Inuit communities, and the authors speculate that the unusual tori patterns were the result of a combination of founder effect and genetic drift.

While most of Structure, function and evolution of teeth is not of direct relevance to anthropologists specialising in northern populations, it is an excellent compilation of some of the most recent and exciting research in the field, and will prove to be a valuable reference source for years to come. (Elizabeth Cruwys, Scott Polar Research Institute, University of Cambridge, Lensfield Road, Cambridge $\mathrm{CB} 2$ 1ER.)

THE FALKLANDS AND THE DWARF: THE CRUISE OF HMS DWARF IN THE FALKLAND ISLANDS 1881-1882. C.H. Layman and J. Cameron. 1995. Chippenham: Picton Publishing. xiv +160 p, illustrated, hard cover. ISBN 0-0948251-76-X. £25.00.

During the late nineteenth century, the Royal Navy undertook a bewildering variety of duties quite apart from participating in the various wars that took place during the period. One of the most important of these was the gathering of intelligence concerning potential enemies, which, as this was the period of 'splendid isolation,' meant, in effect, all of those countries that were not coloured red on the map. Other tasks included hydrographic surveying, the exploration of remoter parts of the globe, and action in aid of the civil power and general policing duties in those British dependencies where such was required and where there was no adequate local machinery for so doing. These latter were often combined with cruises, the ostensible purpose of which was to provide training and to keep ships' crews up to scratch, together with the general showing of the flag.

This entertaining little volume presents a first-hand account of one such voyage, that of HMS Dwarf in the Falkland Islands in 1881-1882. The reason for the visit of the ship to the islands was the enforcement of legislation establishing a close season for sealing. As the government had no effective means for doing this, it requested help from the senior officer of the South East American station, based at Montevideo, who arranged for Dwarf, a small vessel of four guns with a crew of 85 , to undertake the duty. But for a fortunate circumstance, the records of Dwarf $\mathrm{s}$ cruise would have remained as formal reports to the Admiralty, which would now be buried in the naval archives. However, in command of Dwarf was a remarkable officer, Commander Sir William Wiseman, Bt, who wrote a series of detailed letters on the doings of the ship to his wife, and these letters are presented in the book. 
It starts with a brief foreword by Douglas Hurd, the exSecretary of State for Foreign and Commonwealth Affairs. In parenthesis, this reviewer has never understood why publishers seem to believe that the incorporation of a couple of pages by a politician should make a book more attractive to the reader. The introduction, however, by Rear Admiral Layman and Jane Cameron, provides a useful background to the state of the colony at the time and a biography of Wiseman, who had had a distinguished naval career before being assigned to Dwarf. The bulk of the text is pure Wiseman, with a modest critical apparatus.

The letters cover the period 3 December 1881, when Wiseman assumed command of Dwarf at Montevideo, to 14 February 1882 , when Dwarf was on her way back to that port, having completed her duties in the islands. In that time, Dwarf circumnavigated the archipelago. She arrived at Stanley on 23 December 1881, and Wiseman was chagrined to find that the very legislation he was to enforce had not actually been passed by the legislature. This was completed on 27 December, and Dwarf departed on her voyage on 29 December. During her travels, landings were made at many settlements and at uninhabited places. At each of the former, friendly relations were established with the people and there was an extensive social programme. Shooting appears to have been a main preoccupation of the officers of the vessel, and efforts at securing game, both for fresh food and for sport, were made continuously. It all appears to have been very agreeable.

As far as the actual purpose of the voyage was concerned, this was something of an anticlimax, since only two sealers were found, and they were duly warned about the new law.

Wiseman's letters are well-written, entertaining to read, and full of wry comment. They provide much information concerning the islands, their inhabitants, and, in particular, their natural history. The editing is light and effective, and the footnotes and comment are informative but never intrusive. The presentation of the book is pleasant and the illustrations copious and well selected. There is a map providing a track chart of the voyage on the front endpaper, while that at the back is a chart of Stanley harbour. The editors are to be congratulated on unearthing these letters and for the care with which they have undertaken their task.

The book is highly recommended for those with interests in the Falkland Islands. One hopes that the publishers are sufficiently satisfied with the results of this venture that they remain willing to produce similar works relating to other out-of-the-way parts of the world. (Ian R. Stone, The Registry, University of Kent at Canterbury, Canterbury, Kent CT2 7NZ.)

HUSKIES IN HARNESS: A LOVE STORY IN ANTARCTICA. Shelagh Robinson (Editor). 1995. Kenthurst, NSW: Kangaroo Press. 144 p, illustrated, soft cover. ISBN 0-86417-726-7. \$Aus29.95.

As part of its implementation of the Madrid Protocol, in 1992 the Australian Antarctic Division relocated the last huskies at Mawson Station to Australia and North America, thus ending more than 40 years' involvement of huskies in Australian National Antarctic Research Expeditions (ANARE).

Shelagh Robinson has brought together more than 45 works about huskies, from government policy behind their relocation, to personal accounts and poems about the significance of the huskies at several Australian stations and bases, as well as coverage on British Antarctic Survey activities. The work, however, is much more than a compendium of stories.

Firstly, it is very likely the first major popular work on ANARE to actively embrace the wide cross-section of people that have participated in its 50-year history remarkable testimony itself of how the huskies' relocation galvanised opinion among past and present expeditioners.

Secondly, anybody interested in Antarctica will recognise that most of the book's contributions are written from the heart. The rich and frank language, and the sense of humour that is central to expeditions, runs through the book - rare qualities in most contemporary works on Antarctica. Extended husky trips in Antarctica are not for the faint-hearted, and this comes through in the stories about training and running huskies.

Finally, the book is an important historic piece on ANARE and a companion to Bob Dovers' book (Dovers 1957) on his experiences with huskies with the 1951-1952 French Expedition. Dovers subsequently led the establishment of Mawson Station and mapping of Mac. Robertson Land using huskies.

This eclectic work adds greatly to the understanding of the contribution made by huskies to Antarctica, from heroic to modern times. (Peter Keage,Tourism Victoria, 11 th Floor, 55 Swanston Street, Melbourne, Australia 3001.)

\section{Reference \\ Dovers, R. 1957. Huskies. London: G.Bell and Sons.}

\section{BRIEF REVIEWS}

ALASKAN ESKIMO LIFE IN THE 1890s AS SKETCHED BY NATIVE ARTISTS. George Phebus Jr. 1995. Fairbanks: University of Alaska Press. 168 p, Illustrated, soft cover. ISBN 0-912006-79-X. £18.95.

This is a reprint of the well-known book published by the Smithsonian Institution Press in 1972. In it is reproduced a series of sketches, mostly in pencil, ink, crayon, or watercolour, by native peoples of Alaska and depicting the Arctic landscape and scenes of their daily lives. The sketches were discovered in an old storage unit at the Smithsonian in 1967. Phebus, who was then on the staff of the Smithsonian Department of Anthropology, concluded that the sketches had been prepared during the 1890 s by pupils of Alaskan schools and realised their value as providing 'a record of Alaskan Eskimo life...just prior to the drastic changes of the 20th century.'

The sketches are divided into generic groupings, of 